\title{
Experimental Small Scale Solar Power Tower in Iraq
}

\author{
Ghanim Kadhim Abdulsada ${ }^{1}$ and Afreen Emad Sa'ad-Aldeen ${ }^{2}$ \\ 1. Mechanical Engineering Dept., Al-Mustansiriyah University, Baghdad 964, Iraq \\ 2. Materials Engineering Dept., Al-Mustansiriyah University, Baghdad 964, Iraq
}

Received: October 26, 2015 / Accepted: November 17, 2015 / Published: January 31, 2016.

\begin{abstract}
Solar energy is the most available, clean and inexpensive source of energy among the other renewable sources of energy. This work deals with experimental steady to determent the performance of solar tower steam production for power generation. Designed and fabricated of a solar tower, consist of a central receiver tank $(0.4 \mathrm{~m} \times 0.6 \mathrm{~m} \times 1.0 \mathrm{~m})$ and 150 heliostat mirrors arranged around it. The central tank was made of galvanized steel. Each heliostat consisted of two $(0.5 \mathrm{~m} \times 0.5 \mathrm{~m})$ mirrors. The results of this work produce steam at temperature $110^{\circ} \mathrm{C}$. Large steam quantity could be obtained when using large scale experimental. The results of the work give good indication for application of solar energy to produce power in Iraq.
\end{abstract}

Key word: Solar central tower, heliostat, steam generation, concentration system.

\section{Nomenclature}

$\begin{array}{ll}A_{a} & \text { Aperture area }\left(\mathrm{m}^{2}\right) \\ A_{r} & \text { Receiver area }\left(\mathrm{m}^{2}\right) \\ C R & \text { Concentration ratio } \\ D & \text { Diameter of dish }(\mathrm{m}) \\ d & \text { Diameter of coil }(\mathrm{m}) \\ I_{a} & \text { Incident radiation }\left(\mathrm{W} / \mathrm{m}^{2}\right) \text { at } 11: 00 \text { a.m., September } \\ & 7,2014 \text { in Iraq } / \text { Baghdad } \\ Q_{a b s} & \text { Energy collected by the absorber }(\mathrm{W}) \\ Q_{\text {loss }} & \text { Receiver energy losses }(\mathrm{W}) \\ Q_{u} & \text { Useful energy transferred to working fluid }(\mathrm{W}) \\ T_{a} & \text { Ambient temperature }\left({ }^{\circ} \mathrm{C}\right) \\ T_{c} & \text { Collector temperature }\left({ }^{\circ} \mathrm{C}\right) \\ U_{r} & \text { Absorber heat losses coefficient }\left(\mathrm{W} /\left(\mathrm{m}^{2} \cdot{ }^{\circ} \mathrm{C}\right)\right) \\ \eta_{c o l l e c t o r} & \text { The efficiency of collector } \\ \alpha \tau & \text { Transmittance of any glass envelope covering the } \\ & \text { receiver }\end{array}$

\section{Introduction}

Solar energy is the most available, clean and inexpensive source of energy among the other renewable sources of energy. Iraq is an encouraging location for the development of solar energy systems due to abundant sunshine $(3,700 \mathrm{~h} /$ year $)$. The solar radiation is available with high intensity yearly average about $7 \mathrm{kWh} /\left(\mathrm{m}^{2} \cdot\right.$ day) $[1,2]$. The method of using solar

Corresponding author: Ghanim Kadhim Abdulsada, professor, research fields: renewable energy and heat transfer. energy for produce steam is concentrating central tower receiver system, which consist of central receiver tank and a number of heliostat are arranged around it. The development of thermo solar plants with CTRs (central tower receivers) has started around the 70's, as well as PTC (power tower concentrating), and during 25 years, they were implemented and tested as demonstration models in many countries around the world, particularly in the USA and Spain [3, 4].

In this work, solar power tower technology is examined for collecting and redirecting solar energy in order to produce steam for power generation in Iraq.

By design and fabricate solar tower consist of a central receiver rectangular tank $(0.4 \mathrm{~m} \times 0.6 \mathrm{~m} \times 1 \mathrm{~m})$, and 150 heliostat are arranged around tank, each heliostat has consisted of two $(0.5 \mathrm{~m} \times 0.5 \mathrm{~m})$ mirrors as shown in Fig. 1. Central tank was made of galvanized steel.

\section{Mathematical Model}

The receiver is the part of the system that converts solar radiation to thermal energy in a working fluid. The receiver consists of an absorber, heat exchanger and possibly heat storage $[5,6]$. 


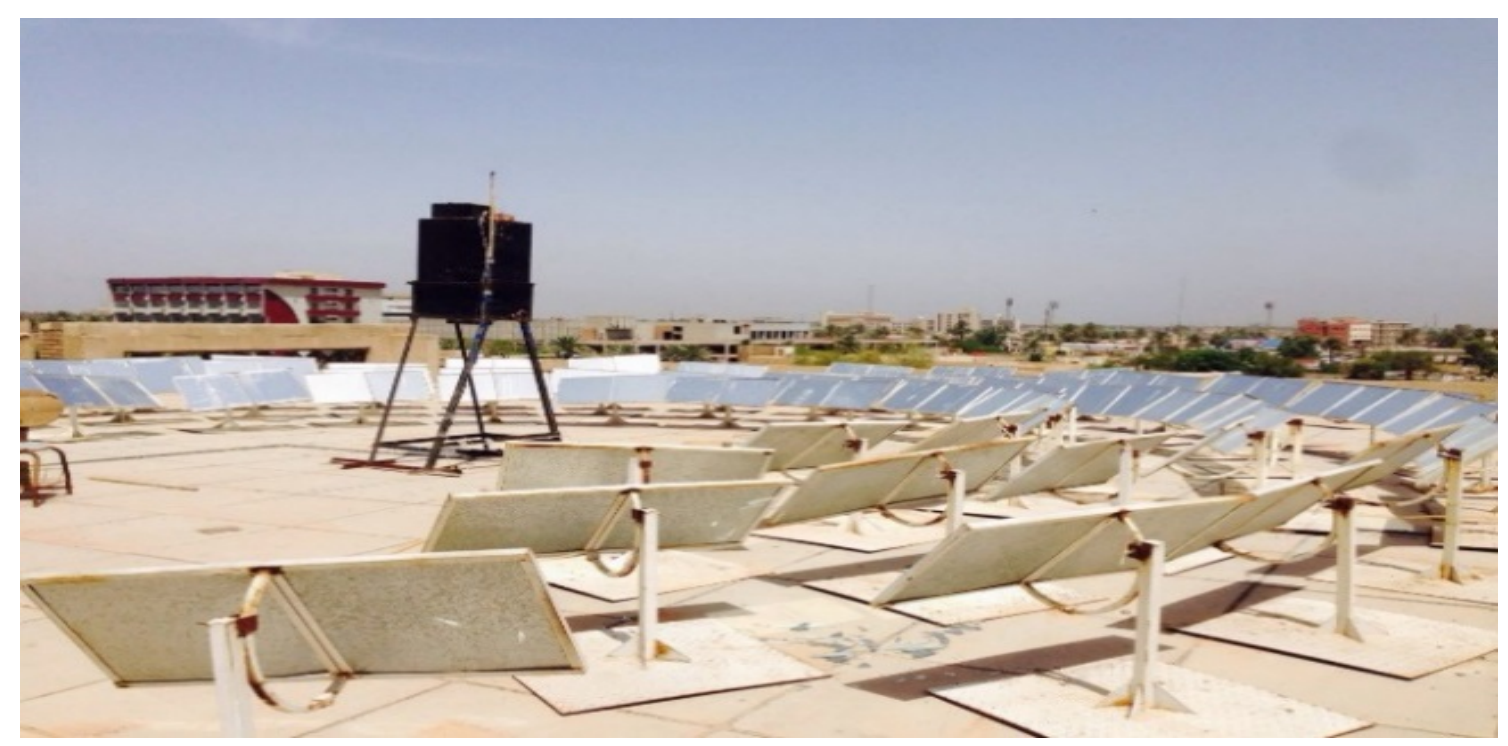

(a)

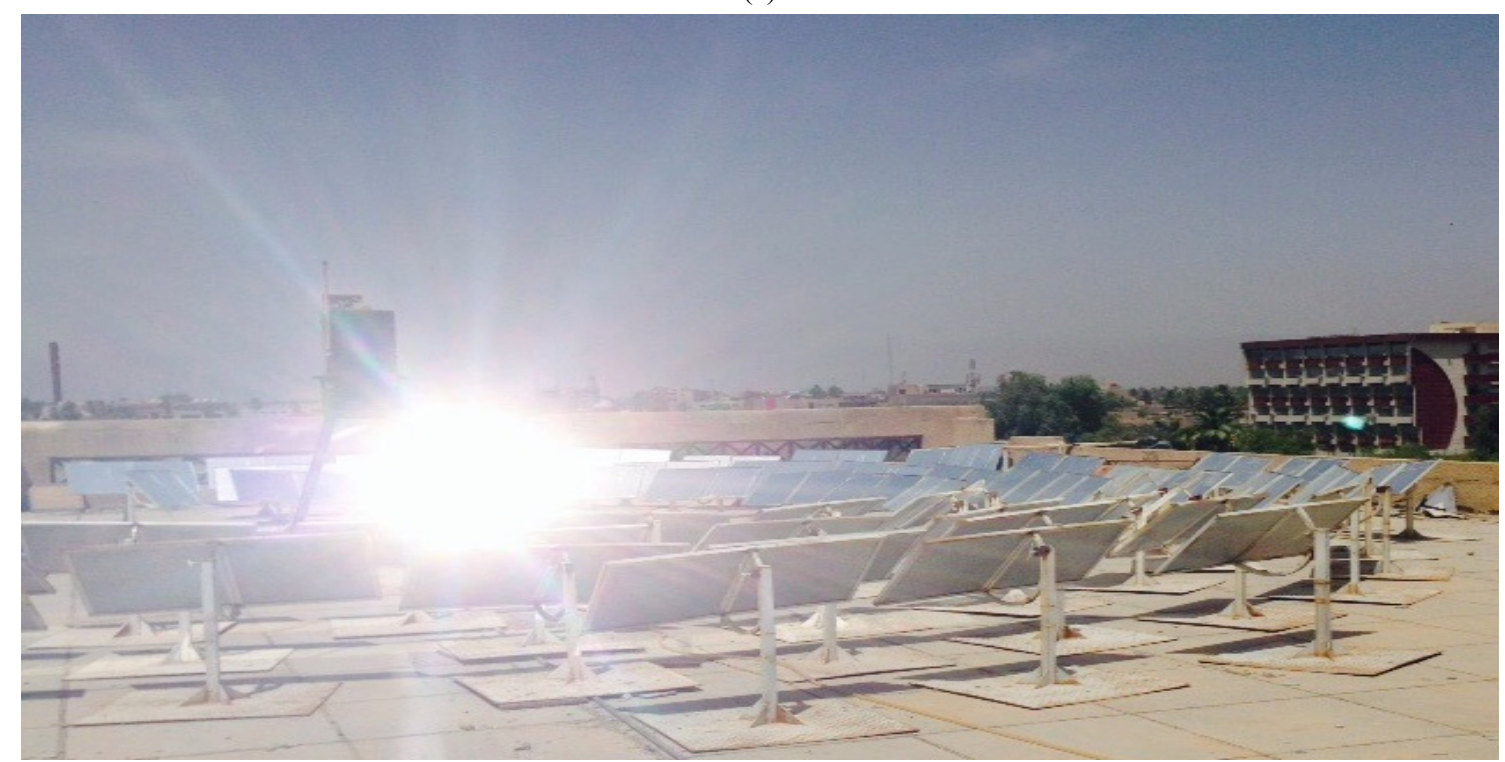

(b)

Fig. 1 The central receiver tower system: (a) arrangement of heliostat around the central receiver, (b) the high intensity of solar energy.

The absorber is the impinging surface for reflected solar radiation. Radiation is absorbed into the absorber material as heat. The heat exchanger transfers the energy to a working fluid that carries the energy out of the receiver. Eq. (1) shows an energy balance for a receiver.

$$
Q_{\text {out }}=Q_{a b s}-Q_{\text {loss }}
$$

The useful energy by concentrator is given:

$$
Q_{u}=A_{a} \cdot \eta_{c} \cdot I_{c}-A_{r} \cdot U_{r}\left(T_{c}-T_{a}\right)
$$

The collector efficiency is given by:

$$
\eta_{c}=\eta_{o}-\left(A_{a} / A_{r}\right)\left(U_{c}\left(T_{c}-T_{a}\right) / T_{c}\right)
$$

where

$$
C R=\frac{A_{a}}{A_{r}}
$$

CR (concentration ratio) is the area of the collector Aperture $\left(A_{a}\right)$ divided by the surface area of the receiver $\left(A_{r}\right)[7,8]$.

Eq. (3) may be written as:

$$
\eta_{c}=\eta_{o}-\left(U_{c} / C R\right)\left(\left(T_{c}-T_{a}\right) / T_{c}\right)
$$

The efficiency is most often based on collector fluid 
inlet temperature $\left(T_{f i}\right)[9,10]$. Hence Eq. (5) was written as:

$$
\begin{gathered}
\eta_{c}=F_{r}\left[\eta_{o}-\left(U_{c}\right)\left(\left(T_{c}-T_{a}\right) / T_{c}\right)\right] \\
U_{c}=\left(U_{c} \cdot C R\right) \\
\eta_{o}=\delta \cdot \alpha_{r} \cdot \rho_{m} \cdot \tau_{c} \cdot f_{t} \cdot f_{c i}
\end{gathered}
$$

where, $\rho_{m}$ is mirror reflectance $(0.8-0.9)$; $\tau_{c}$ is receiver transmittance $(0.85-0.92) ; \quad \alpha_{r}$ is receiver surface absorptance (0.9-0.92); $\delta$ is intercept factor for mirror factor surface and tracking error (0.9-0.95).

\section{Experimental Work}

Design and fabricate central receiver tank of galvanized steel $(0.4 \mathrm{~m} \times 0.6 \mathrm{~m} \times 1 \mathrm{~m})$. The steel structures carry the center receiver tank. The storage tank of salt solution made of steel, its dimension $(0.8 \mathrm{~m}$ $\times 1.2 \mathrm{~m})$.

The network piping system supplied water to receiver tank. 150 mirrors $(0.5 \mathrm{~m} \times 0.5 \mathrm{~m})$ arranged around receiver tank, which is tilted at $45^{\circ}$. A set of measuring instrument fixed in many places such us mirror surface, water inlet to the central, water exit from central receiver tank and ambient temperature. After arrangement these system, the receiver tank fill with water up to $75 \%$. Then concentrating all the solar radiations that reflected from the mirrors to the central receiver tank to heat the water inside it. The experimental work runs in Baghdad Iraq (lat. $33 \mathrm{~N}$ ) at September, 2014. Measured temperature of receiver tank at each hour recorded at the data logger system.

\section{Results and Discussion}

The results of this work show in the following figures. The water filled the tank at $38{ }^{\circ} \mathrm{C}$ (Fig. 2). After concentrating the solar radiation to the central receiver tank, the temperature of water inside the tank started increase until generated the steam at $110^{\circ} \mathrm{C}$.

The experimental and theoretical temperatures of receiver tank are shown in Fig. 3.

Another run of the experimental work using the molten salt as the working fluid in the receiver tank. The temperature of tank with the molten salt is

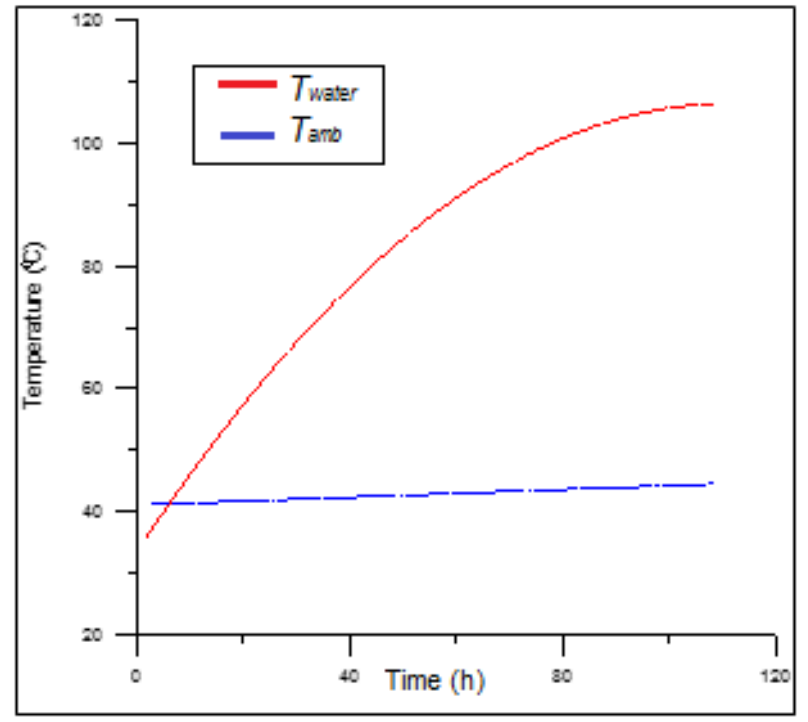

Fig. 2 Variation water tank temperature and ambient temperature with time.

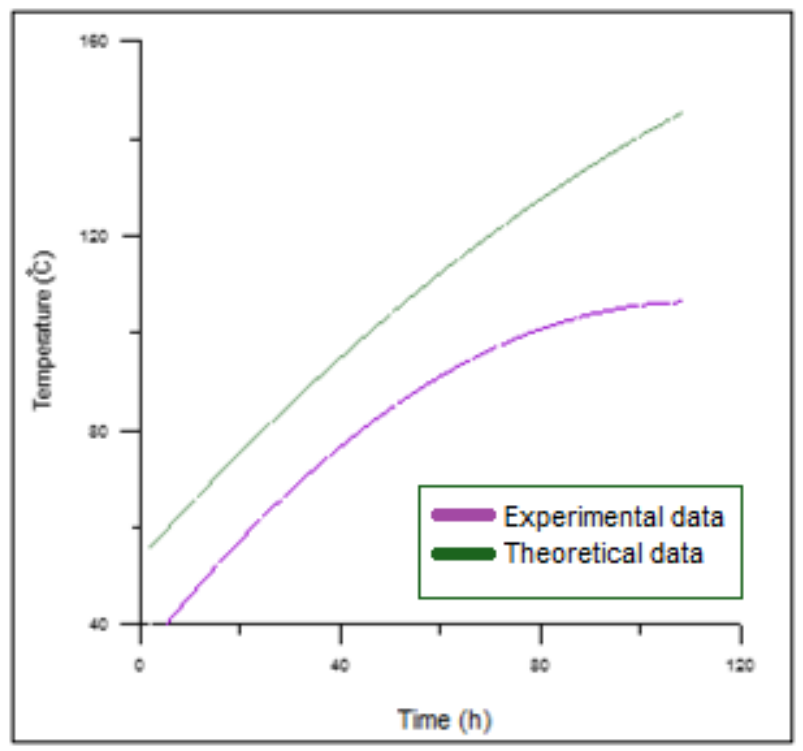

Fig. 3 Experiential and theoretical receiver tank temperature.

increases with short time. This is due to the molten salt exist in the tank, as shown in Fig. 4. Hence the molten salt could be considered good working fluid as well as storage media.

\section{Conclusions}

We conclusion from this study:

(1) It is possible to produce steam for power generation by utilization solar energy in Iraq (hot arid region). 


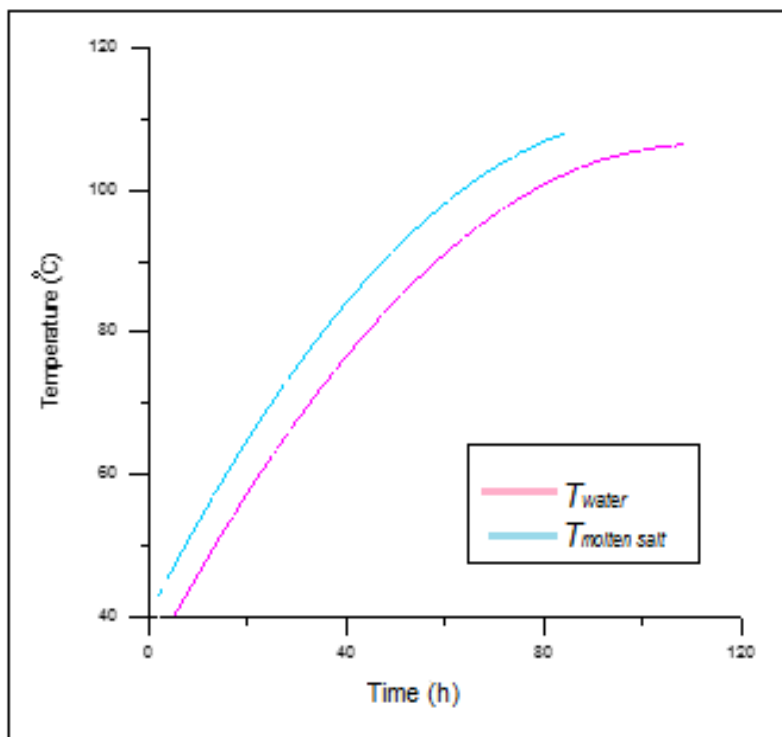

Fig. 4 Compare between temperature of the tank when used water and molten salt as a working fluid.

(2) When used the molten salt as a working fluid, the temperature of water increases within short time.

\section{References}

[1] Barth, D. L., Pacheco, J. E., Kolb, W. J., and Rush, E. E. 2002. "Development of a High Temperature, Long-Shafted, Molten-Salt Pump for Power Tower Applications.” ASME J. Sol. Energy Eng. 124 (2): 170-5.

[2] Chavez, J. M. R., Rush, E. E., Matthews, C. W., Stomp, J.
M., Imboden, J., and Dunkin, S. 1990. An Overview of Advanced Central Receiver Concepts. Sandia National Laboratories report.

[3] Kolb, G. J. 1990. Reliability Analysis of a Salt-in-Tube Central Receiver Power Plant. Sandia National Laboratories report.

[4] Smith, D. C., Rush, E. E., Matthews, C. W., Chavez, J. M., Bator, P. A., and Barberton, O. H. 1991. Report on the Test of the Molten-Salt Pump and Valve Loops. Sandia National Laboratories report.

[5] Pacheco, J. E. 1992. Flow Stability in Molten-Salt Tube Receivers. Sandia National Laboratories report.

[6] Pacheco, J. E. R., Ralph, M. E., and Chavez, J. M. 1994. Investigation of Cold Filling Receiver Panels and Piping in Molten Nitrate-Salt Central- Receiver Solar Power Plants. Sandia National Laboratories report.

[7] Andujar, J. M., Rosa, F., and Geyer, M. 1991. "CESA-1 Thermal Storage System Evaluation.” Sol. Energy 46 (5): 305-12.

[8] Bradshaw, R. W., and Meeker, D. E. 1990. "High-Temperature Stability of Ternary Nitrate Molten Salts for Solar Thermal Energy Systems." Sol. Energy Mater. 21 (1): 51-60.

[9] Chavez, J. M., Reilly, H. E., Kolb, G. J., Gould, B., Zavoico, A., and Sutherland, P. 1995. The Solar Two Power Tower Project: A 10 MWe Power Plant. New York, NY: American Society of Mechanical Engineers, 469-75.

[10] Tyner, C. E., Sutherland, J. P., and Gould, W. R. J. 1995. Solar Two: A Molten Salt Power Tower Demonstration. Sandia National Laboratories report. 